\title{
FORECASTING FARMER EXCHANGE RATE IN CENTRAL JAVA PROVINCE USING VECTOR INTEGRATED MOVING AVERAGE
}

\author{
Trimono $^{1}$, Abdulah Sonhaji ${ }^{2}$, Utriweni Mukhaiyar ${ }^{2}$ \\ ${ }^{1}$ Magister of Mathematics, Institut Teknologi Bandung \\ ${ }^{2}$ Program Study of Mathematics, Institut Teknologi Bandung \\ e-mail: trimono@student.itb.ac.id
}

DOI: $10.14710 /$ medstat.13.2.182-193

\section{Article Info:}

Received: 31 March 2020

Accepted: 21 December 2020

Available Online: 28 December

2020

\section{Keywords:}

Farmer Exchange Rate, Vector Time Series, $\operatorname{VIMA}(2,1), M A P E$

\begin{abstract}
Farmer Exchange Rate (FER) is an indicator that can be used to measure the level of farmers welfare. For every agriculture sector, FER is affected by the historical price of harvest from the corresponding sector and historical prices of other agriculture sectors. In Central Java Province, rice \& palawija, horticulture, and fisheries are the largest agriculture sectors which is the main livelihood for most of the population. FER forecasting is a crucial thing to determine the level of farmers welfare in the future. One method that can be used to predict the value of a variable that is influenced by the historical value of several variables is Vector Time Series. An empirical study was conducted using FER data from the rice \& palawija, horticulture and fisheries sectors for January 2011-June 2017 in Central Java Province. The results obtained show that by using the VIMA(2.1) model, the FER prediction was very accurate, with MAPE values were $1.91 \%$ (rice \& palawija sector), $2.44 \%$ (horticulture sector), and $2.18 \%$ (fisheries sector).
\end{abstract}

\section{INTRODUCTION}

Agriculture is one of the largest sectors that supporting the economy in Central Java Province. During the 2010-2019 period, the Gross Regional Domestic Product (GRDP) of the agriculture sector contributed at least $15 \%$ of the total GRDP of Central Java Province (BPS Provinsi Jawa Tengah, 2020). The agriculture sectors that have the highest contribution are rice and palawija, horticulture and fisheries. This is because the geographic condition of Central Java Province, which in general consists of 3 parts (the lowlands, the highlands, and the coast), so most of the population work as farmers in these three fields.

One of the factors that help the agricultural sector have a high contribution to GRDP is the maximum effort of farmers in cultivating their agricultural land. Therefore, in order, the agricultural sector can still have a significant impact on the economy, the local government should pay attention to farmer welfare. Based on Martina \& Praza (2018), there is a reciprocal relationship between farmer welfare and agriculture production. The higher the level of farmer welfare, the higher agriculture production. The high agriculture 
production will impact on the increase in the value of GRDP in the agricultural sector and the food security of the related area.

Farmer Exchange Rate (FER) is an indicator that can be used to measure the level of farmer welfare and expressed as a percentage. It is obtained from the comparison between the price index received by farmer and the price index paid by farmer (Keumala \& Zainuddin, 2018). Putri \& Noor (2018) state that there is no measure of welfare for farmers other than FER. Hence, FER is the only choice for government and agricultural development observers to measure the level of farmer welfare. Referring to the condition that the agriculture sector gives high contribution to the GRDP of Central Java Province, it is important to know the magnitude of the prediction of the FER. In addition to knowing a picture of farmer welfare, the government can also use FER value prediction as a guideline for taking steps to increase farmer welfare (Nirmala et al., 2016).

According to Desvina \& Meijer (2018), forecasting FER for the upcoming period can be done by utilizing the historical data of FER. Rachmat (2013) states that in a particular area, the value of FER tends to correlate with the other FER from different agriculture sectors. It is due to the harvest price for each sector is related to the others. The two previous explanations are strong enough to serve as a reference that the Vector Time Series method can be used to forecast the FER value. The Vector Time Series model was built to forecast multivariate time series data, with the main assumption that is the data is stationary (Zadrozny \& Chen, 2019). There have been many studies exploring FER predictions. Istiqomah \& Darsyah (2018) predicted farmer Exchange Rate in Central Java Province using the ARIMA and Exponential Smoothing methods. Nirmala et al. (2016) analyzed the factors that affect the FER in Jombang Regency using the multiple regression method. Setiawan et al. (2018) used descriptive analysis to analyze the welfare of soybean farmers in Jatiwaras District, Tasikmalaya Regency.

Based on several previous studies, this research will examine Vector Integrated Moving Average (VIMA) model to forecast the FER of rice \& palawija, horticulture, and fisheries agriculture sector in Central Java Province. Then, to test the accuracy of the forecasts, the MAPE value will be used.

\section{Theoritical Framework}

\subsection{Vector Auto Regressive Moving Average (VARMA)}

In some case, time series data can also consist of several variables, it is called a multivariate time series. Suppose that $\mathbf{Z}_{\mathbf{t}}$ is a vector time series from $m$ correlated variables. The equation for $\operatorname{VARMA}(p, q)$ model generally can be written as (Wei, 2006):

$$
\boldsymbol{\Phi}_{p}(B) \mathbf{Z}_{t}=\boldsymbol{\Theta}_{q}(B) \mathbf{a}_{t}
$$

with,

$$
\begin{aligned}
& \mathbf{Z}_{\mathrm{t}} \quad \text { : multivariate time series vector sized } m \times 1 \\
& \boldsymbol{\Phi}_{p} \text { and } \boldsymbol{\Theta}_{q} \text { : autoregressive (AR) and moving average (MA) nonsingular } \\
& \text { polynomial matrix sized } m \times m \text {. } \\
& m \quad \text { : amount of variable } \\
& \boldsymbol{\Phi}_{p}=\Phi_{0}-\Phi_{1} B-\Phi_{2} B^{2}-\ldots-\Phi_{p} B^{p} \\
& \boldsymbol{\Phi}_{p}=\Theta_{0}-\Theta_{1} B-\Theta_{2} B^{2}-\ldots-\Theta_{q} B^{q}
\end{aligned}
$$




\subsection{Model Vector Moving Average (VMA)}

The VMA is a specific model of VARMA (p,q) when the order of $p$ is 0 . The formula for VMA(q) model for $m$ variables is Dias \& Kapetanios (2014):

$$
\begin{aligned}
& \mathbf{Z}_{t}=\left(\mathbf{I}-\boldsymbol{\Theta}_{1} B-\boldsymbol{\Theta}_{2} B^{2}-\ldots-\boldsymbol{\Theta}_{q} B^{q}\right) \mathbf{a}_{t} \\
& \mathbf{Z}_{t}=\mathbf{a}_{t}-\boldsymbol{\Theta}_{1} \mathbf{a}_{t-1}-\boldsymbol{\Theta}_{2} \mathbf{a}_{t-2}-\ldots-\boldsymbol{\Theta}_{q} \mathbf{a}_{t-q}
\end{aligned}
$$

in matrix notation, $\operatorname{VMA}(q)$ model is written:

$$
\begin{aligned}
{\left[\begin{array}{c}
Z_{1, t} \\
Z_{2, t} \\
\vdots \\
Z_{m, t}
\end{array}\right]=} & {\left[\begin{array}{cccc}
1 & 0 & \cdots & 0 \\
0 & 1 & \cdots & 0 \\
\vdots & \vdots & \ddots & \vdots \\
0 & 0 & \cdots & 1
\end{array}\right]\left[\begin{array}{c}
a_{1, t} \\
a_{2, t} \\
\vdots \\
a_{m, t}
\end{array}\right]-\left[\begin{array}{cccc}
\theta_{1,1-1} & \theta_{1,1-2} & \ldots & \theta_{1,1-m} \\
\theta_{1,2-1} & \theta_{1,2-2} & \ldots & \theta_{1,2-m} \\
\vdots & \vdots & \ddots & \vdots \\
\theta_{1, m-1} & \theta_{1, m-2} & \ldots & \theta_{1, m-m}
\end{array}\right]\left[\begin{array}{c}
a_{1, t-1} \\
a_{2, t-1} \\
\vdots \\
a_{m, t-1}
\end{array}\right]-\left[\begin{array}{cccc}
\theta_{2,1-1} & \theta_{2,1-2} & \ldots & \theta_{2,1-m} \\
\theta_{2,2-1} & \theta_{2,2-2} & \ldots & \theta_{2,2-m} \\
\vdots & \vdots & \ddots & \vdots \\
\theta_{2, m-1} & \theta_{2, m-2} & \ldots & \theta_{2, m-m}
\end{array}\right]\left[\begin{array}{c}
a_{1, t-2} \\
a_{2, t-2} \\
\vdots \\
a_{m, t-2}
\end{array}\right] } \\
& m \times 1 \times 1 \times m \times 1 \\
& -\ldots-\left[\begin{array}{cccc}
\theta_{q, 1-1} & \theta_{q, 1-2} & \ldots & \theta_{q, 1-m} \\
\theta_{q, 2-1} & \theta_{q, 2-2} & \ldots & \theta_{q, 2-m} \\
\vdots & \vdots & \ddots & \vdots \\
\theta_{q, m-1} & \theta_{q, m-2} & \ldots & \theta_{q, m-m}
\end{array}\right]\left[\begin{array}{c}
a_{1, t-q} \\
a_{2, t-q} \\
\vdots \\
a_{m, t-q}
\end{array}\right] \\
& m \times m
\end{aligned}
$$

with,

$\mathbf{Z}_{i, t}$ : vector of the $\mathrm{i}^{\text {th }}$ variable at $\mathrm{t}^{\text {th }} \operatorname{lag}(i=1,2, \ldots, m$ and $t=1,2, \ldots, T)$.

$\boldsymbol{\Theta}_{q}:$ vector of $\operatorname{VMA}(\mathrm{q})$ parameter coefficient at $(t-q)^{\mathrm{th}}$ lag.

$\mathbf{a}_{t} \quad$ : vector of error model at the $\mathrm{t}^{\text {th }}$ lag.

$\mathbf{a}_{t-q}$ : vector of error model at the $(t-q)^{\text {th }}$ lag.

\subsection{Model Vector Integrated Moving Average (VIMA)}

The Autoregressive Integrated Moving Average (VIMA) as one of vector time series model is useful for predicting multivariate time series data when the data is not satisfying stationary assumption. The VIMA model comes from VMA (q) model with a non-stationary initial process (Ayudhiah et al., 2020). When the order of VMA and differentiation respectively is $q$ and $d$, a new model is obtained, namely VIMA $(d, q)$. In general, the VIMA $(d, q)$ model is as written below:

$$
(1-B)^{d} \mathbf{Z}_{t}=\boldsymbol{\Theta}_{q}(B) \mathbf{a}_{t}
$$

As an example, when the order of $q$ and $d$ is 1 and 2 , so the formula for $\operatorname{VIMA}(2,1)$ is:

$$
\begin{aligned}
& (1-B)^{2} \mathbf{Z}_{t}=\boldsymbol{\Theta}_{q}(B) \mathbf{a}_{t} \\
& \Leftrightarrow\left(1-2 B-B^{2}\right) \mathbf{Z}_{t}=\mathbf{a}_{t}-\boldsymbol{\Theta}_{1} \mathbf{a}_{t-1} \\
& \Leftrightarrow \mathbf{Z}_{t}-2 \mathbf{Z}_{t-1}+\mathbf{Z}_{t-2}=\mathbf{a}_{t}-\boldsymbol{\Theta}_{1} \mathbf{a}_{t-1} \\
& \Leftrightarrow \mathbf{Z}_{t}=2 \mathbf{Z}_{t-1}-\mathbf{Z}_{t-2}+\mathbf{a}_{t}-\boldsymbol{\Theta}_{1} \mathbf{a}_{t-1}
\end{aligned}
$$


Equation (5) can be written in matrix notation as:

$$
\left[\begin{array}{c}
Z_{1, t} \\
Z_{2, t} \\
\vdots \\
Z_{m, t}
\end{array}\right]=\left[\begin{array}{c}
2 Z_{1, t-1} \\
2 Z_{2, t-1} \\
\vdots \\
2 Z_{m, t-1}
\end{array}\right]-\left[\begin{array}{c}
Z_{1, t-2} \\
Z_{2, t-2} \\
\vdots \\
Z_{m, t-2}
\end{array}\right]+\left[\begin{array}{cccc}
1 & 0 & \ldots & 0 \\
0 & 1 & \ldots & 0 \\
\vdots & \vdots & \ddots & \vdots \\
0 & 0 & \ldots & 1
\end{array}\right]\left[\begin{array}{c}
a_{1, t} \\
a_{2, t} \\
\vdots \\
a_{m, t}
\end{array}\right]-\left[\begin{array}{cccc}
\theta_{1,1-1} & \theta_{1,1-2} & \ldots & \theta_{1,1-m} \\
\theta_{1,2-1} & \theta_{1,2-2} & \ldots & \theta_{1,2-m} \\
\vdots & \vdots & \ddots & \vdots \\
\theta_{1, m-1} & \theta_{1, m-2} & \ldots & \theta_{1, m-m}
\end{array}\right]\left[\begin{array}{c}
a_{1, t-1} \\
a_{2, t-1} \\
\vdots \\
a_{3, t-1}
\end{array}\right]
$$

\subsection{Steps of Vector Time Series Modeling \\ 2.3.1.Stationary Test}

The first step of vector time series modeling is test of stationarity. This test needs to be done because the vector time series model requires stationary assumption (Charles et al., 2015). Several methods that can be used for the stationarity test are Dickey-Fuller, Augmented Dickey-Fuller, and Phillips-Perron. If the results show that the data is not stationary, then a differencing process must be done.

\subsubsection{Model Identification}

The model identification for vector time series is carried out on data that has been stationary. The order for VARMA $(p, q)$ and VARIMA $(p, d, q)$ models can be seen through the ACF and PACF plots formed from each of the variables. The reference for model estimation based on ACF and PACF plots according to Simionescu (2013) is as follows:

Table 1. Estimation Model Based on ACF and PACF Plots

\begin{tabular}{ccc}
\hline Model & ACF & PACF \\
\hline $\operatorname{VAR}(p)$ & Tails off & Cut off after $p^{\text {th }}$ lag \\
VMA $(q)$ & Cut off after $q^{\text {th }}$ lag & Tails off \\
VARMA $(p, q)$ & Tails off after $p^{\text {th }} l a g$ & Tails off after $q^{\text {th }}$ lag \\
\hline
\end{tabular}

After the model was identified, the next process is performing parameter estimation for each possible model. The parameters that have been obtained need to be tested to see whether the value is significant or not.

\subsubsection{Model Verification}

Model verification is a process to checked whether the estimated model fits with the data. The model verification consists of residual independence and residual normality test (Chen et al., 2017).

a. Residual independence test

One way to test the independence of the residual is through the Ljung-Box test. This test is carried out by utilizing the $\mathrm{Q}$ test statistics value calculated by the autocorrelation value of the residuals. The testing hypothesis is as follows:

$\mathrm{H}_{0}: \rho_{1}=\rho_{2}=\ldots=\rho_{T}$ (there are no residual correlation between the lags).

$\mathrm{H}_{0}$ : there is at least one $k$ such that $\rho_{k}$, with $k=1,2, \ldots, j$ (there are residual correlation between the lags).

Test statistic:

$$
Q_{j}=n(n+2) \sum_{k=1}^{j}(n-k)^{-1} \rho_{k}^{2}
$$


with,

$n$ : sample size,

$j \quad$ : the number of lags tested,

$\rho_{k}$ : residual autocorrelation at $k^{\text {th }} \mathrm{lag}$,

$Q$ following Chi-Square distribution with degre of freedom is $m$.

Note: The Q value is calculated for each lag, so there are several Q values in one model.

Critical value:

$\mathrm{H}_{0}$ is rejected if $Q_{j}>\chi_{(j)}^{2}$ or $\mathrm{p}$-value $<\alpha$

\section{b. Residual normality test}

One of a method for testing of residual normality is the Jarque-Berra test. The hypothesis is as follows:

$\mathrm{H}_{0}$ : Residual following Normal distribution

$\mathrm{H}_{1}$ : Residual not following Normal distribution

Test statistic:

$$
\mathrm{JB}=\frac{n}{6}\left(S^{2}+\frac{(K-3)^{2}}{4}\right)
$$

with

$n$ : sample size

$S$ : the residual skewness value

$K$ : the residual kurtosis value

Critical value:

$\mathrm{H}_{0}$ is rejected if $Q_{j}>\chi_{(j)}^{2}$ or $\mathrm{p}$-value $<\alpha . \mathrm{H}_{0}$ ditolak jika JB $>\chi_{(2)}^{2}$ atau p-value $<\alpha$

\subsubsection{Best Model Selection}

The best model selection is determined by measure the quality of predictive model. It can be done by using Akaike's Information Criterion (AIC) value (Zhao \& Qian, 2014). The best model is those with the lowest AIC values. The formula for obtaining the AIC value is written as follows:

$$
\mathrm{AIC}=-2 \ln (L)+2 u
$$

with

$n$ : sample size

$L$ : Likelihood function value that obtained from parameter estimation

$u$ : the number of parameters in the model that will be tested

\subsection{Model Performance Measures}

Each prediction process always contains an element of uncertainty that known as residual. Then, the residual value is used as a benchmark for forecast accuracy. The smaller the residual value, the more accurate the prediction results (Moreno et al., 2013). The forecast accuracy can be measured using the Mean Absolute Percentage Error (MAPE). 
According to Maruddani \& Trimono (2018), MAPE is a method commonly used to evaluate predictive value by considering the effect of actual value. The MAPE equation is as follows:

$$
M A P E=\frac{\sum_{p=1}^{n}\left|\frac{Y_{p}-F_{p}}{Y_{p}}\right|}{n} \times 100 \%
$$

with :

$$
\begin{aligned}
& Y_{p}: \text { actual value at } p^{\text {th }} \text { period } \\
& F_{p}: \text { forecast value at } p^{\text {th }} \text { period } \\
& n \quad: \text { sample size }
\end{aligned}
$$

Table 2. A Scale of Judgment of Forecast Accuracy

\begin{tabular}{cc}
\hline Nilai MAPE & Judgment of Forecast Accuracy \\
\hline$<10 \%$ & Highly accurate \\
$11 \%-20 \%$ & Good forecast \\
$21 \%-50 \%$ & Reasonable forecast \\
$>51 \%$ & Inaccurate forecast \\
\hline
\end{tabular}

\section{RESEARCH METHOD}

\subsection{Data and Programming}

This study analyzed the monthly data of the FER value of rice and palawija, horticulture, and fisheries agriculture sector in Central Java Province from January 2011 to December 2017. The data was taken from the annual book "Central Jawa Province in Numbers", and can be downloaded from the website of Central Bureau of Statistics at https://jateng.bps.go.id/publication/. All of the analysis in this research was used $\mathrm{R}$ and $\mathrm{R}$ Studio software (R. Free Software Foundation's GNU General Public License., 2020)

\subsection{Research Variables}

This research consist of 3 variables i.e:

1. The FER value of rice \& palawija agriculture sector in Central Java Province from January 2011 to December 2017

2. The FER value of horticulture agriculture sector in Central Java Province from January 2011 to December 2017

3. The FER value of fisheries agriculture sector in Central Java Province from January 2011 to December 2017

\subsection{Analysis Steps}

The steps to analyze data are listed in the followings:

1. Collecting NTP data for the rice \& palawija, horticulture, and fisheries agriculture sectors

2. Perform descriptive analysis of the NTP value

3. Carrying out stationarity test in average using the Augmented Dickey-Fuller Test. If the data are not stationary in the average, they are transformed

4. Identifying the VIMA model using ACF and PACF plots

5. Performing parameter estimation and parameter significance test of the VIMA model 
6. Verifying the VIMA model, which includes residual independence test and residual normality test

7. Forecasting he value of NTP for the next several periods

8. Measuring forecast accuracy using MAPE

\section{RESULT AND DISUCSSION}

\subsection{Data Description}

This study analyzed the data of the FER value of rice \& palawija, horticulture, and fisheries agriculture sector in Central Java Province from January 2011 to December 2017. The data were divided into in-sample data from January 2011 to June 2017 which were used as training data and out sample data from July 2017 to December 2017 which were used to test the prediction accuracy. The plot of NTP data movement can be seen in Figure 1.

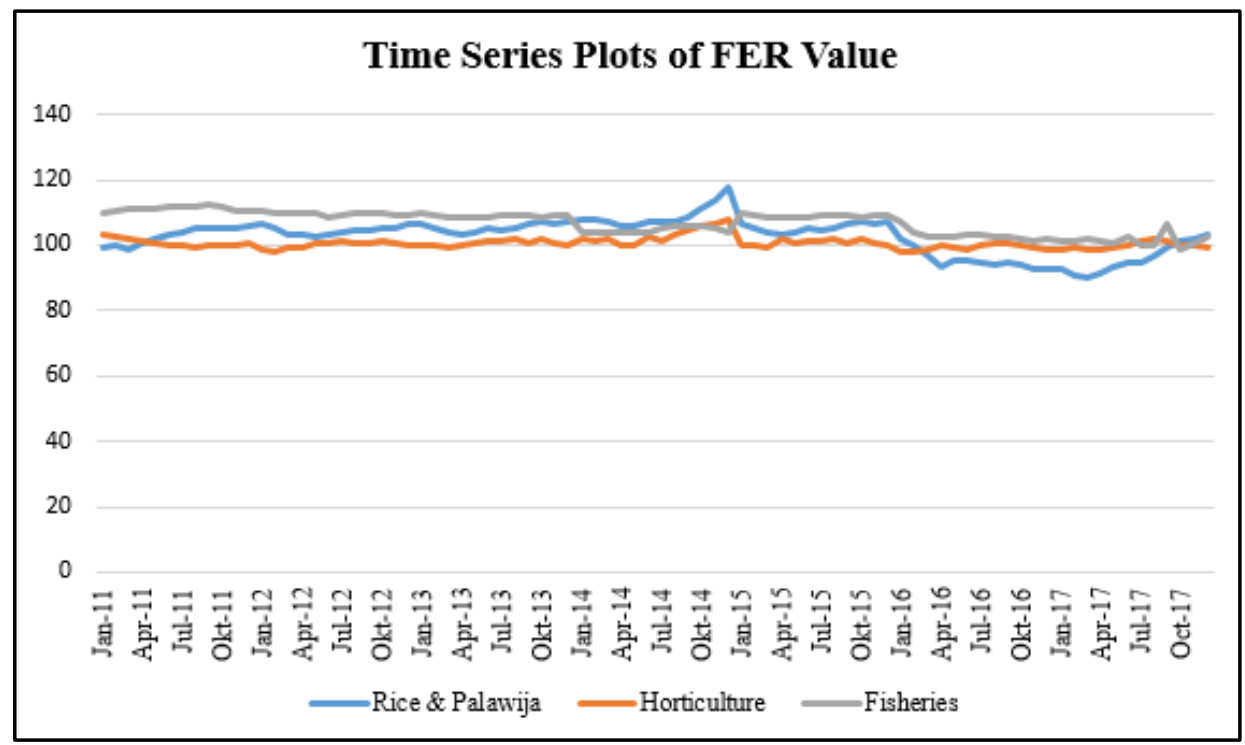

Figure 1. FER Plots

Based on the time series plot, it can be seen that the value of FER is quite volatile. As a note, on September 2015 to January 2016 the value of fer has decreased significantly, it was because during that period there was harvest failure. Then, the descriptive statistics of FER value presented in Table 3 .

Table 3. Descriptive statistics of FER value

\begin{tabular}{lccc}
\hline & Rice \& Palawija & Horticulture & Fisheries \\
\hline Minimum & 90 & 97.650 & 100.520 \\
Maximum & 117.730 & 117.640 & 118.260 \\
Average & 102.884 & 100.601 & 107.968 \\
St. dev & 5.506 & 4.730 & 3.820 \\
Skewness & -0.609 & 1.665 & 0.458 \\
Kurtosis & 0.201 & 4.379 & 1.059 \\
\hline
\end{tabular}

In overall, the descriptive statistics of the three variables have similar values, so there is a possibility that these variables had a strong correlation. Through the Pearson correlation method, the correlation values are obtained as follows: 
Table 4. The Correlation Value Between Sectors

\begin{tabular}{cccc}
\hline & Rice \& Palawija & Horticulture & Fisheries \\
\hline Rice \& Palawija & 1 & 0.581 & 0.864 \\
Horticulture & 0.581 & 1 & 0.802 \\
Fisheries & 0.864 & 0.802 & 1 \\
\hline
\end{tabular}

Because it was proven that there was a significant correlation between these variables, then the Vector Time Seris model can be used to predict FER value.

\subsection{Model Identification}

The first step of Vector Time Series modeling is stationarity test. This test was done with Augmented Dickey-Fuller test. The results obtained are as follows:

Table 5. Stationarity Test for Preliminary and $2^{\text {nd }}$ Differencing Data

\begin{tabular}{ccccc}
\hline \multirow{2}{*}{ NTP } & \multicolumn{2}{c}{ Preliminary data } & \multicolumn{2}{c}{$\mathbf{2}^{\text {nd }}$ Differencing Data } \\
\cline { 2 - 5 } & t-statistic & p-value & t-statistic & p-value \\
\hline Rice and Palawija & -1.1640 & 0.6861 & -13.7818 & 0.0001 \\
Horticulture & -3.5043 & 0.0104 & -8.9359 & 0.0000 \\
Fisheries & -1.1668 & 0.6850 & -15.0274 & 0.0001 \\
\hline
\end{tabular}

Based on Table 5, it is concluded that the data has been stationary at second differencing. Then, to identify model which are possible for the data are used ACF and PACF plots. The $\mathrm{ACF}$ and PACF plots for $2^{\text {nd }}$ differencing data are:

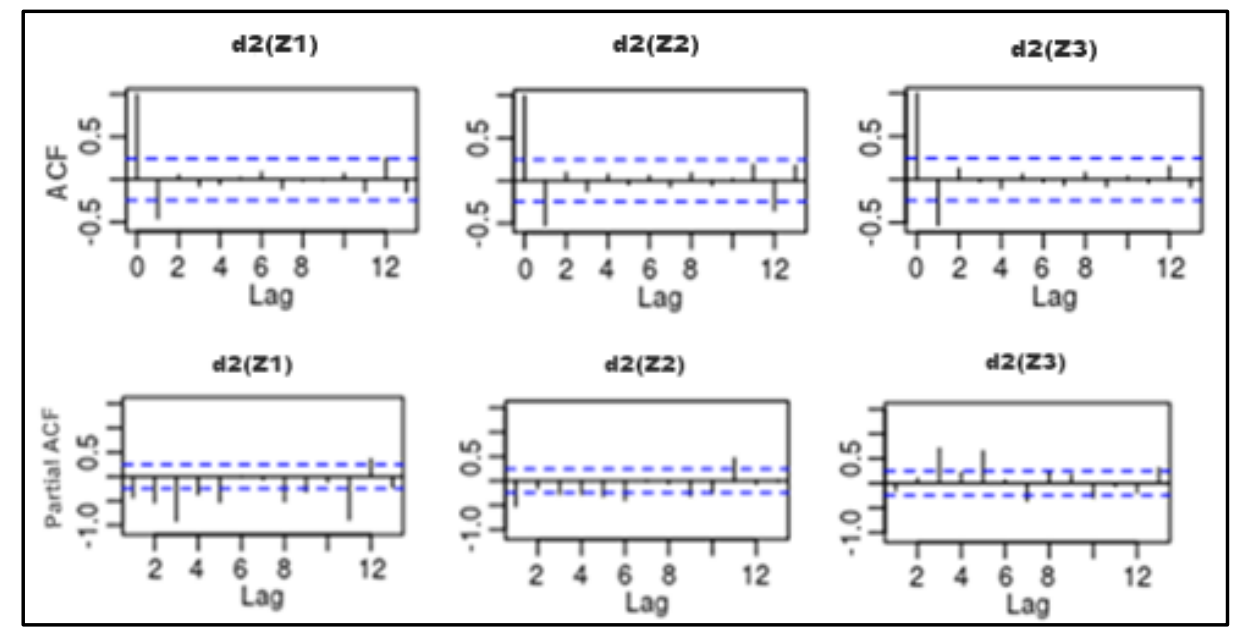

Figure 2. ACF and PACF Plots for $2^{\text {nd }}$ Differencing Data of FER

note: $\mathrm{d}_{2}\left(Z_{1}\right), \mathrm{d}_{2}\left(Z_{2}\right), \mathrm{d}_{2}\left(Z_{3}\right)$ are $2^{\text {nd }}$ differencing data for FER of rice $\&$ palawija, horticulture, and fisheries, respectively.

From Figure 2, the ACF plots was cut off after lag 1, and the PACF plots were tail off, so the possible model is $\operatorname{VIMA}(2,1)$. Through R-GUI programming, the parameter estimates are obtained as follows:

$$
\mathbf{Z}_{t}=\mathbf{Z}_{t-1}+\mathbf{a}_{t}-\boldsymbol{\Theta}_{1} \mathbf{a}_{t-1}
$$




$$
\begin{aligned}
& {\left[\begin{array}{l}
Z_{1, t} \\
Z_{2, t} \\
Z_{3, t}
\end{array}\right]=\left[\begin{array}{l}
Z_{1, t-1} \\
Z_{2, t-1} \\
Z_{3, t-1}
\end{array}\right]+\left[\begin{array}{lll}
1 & 0 & 0 \\
0 & 1 & 0 \\
0 & 0 & 1
\end{array}\right]\left[\begin{array}{l}
a_{1, t} \\
a_{2, t} \\
a_{3, t}
\end{array}\right]-\left[\begin{array}{lll}
\theta_{1,1-1} & \theta_{1,1-2} & \theta_{1,1-3} \\
\theta_{1,2-1} & \theta_{1,2-2} & \theta_{1,2-3} \\
\theta_{1,3-1} & \theta_{1,3-2} & \theta_{1,3-3}
\end{array}\right]\left[\begin{array}{l}
a_{1, t-1} \\
a_{2, t-1} \\
a_{3, t-1}
\end{array}\right]} \\
& {\left[\begin{array}{l}
Z_{1, t} \\
Z_{2, t} \\
Z_{3, t}
\end{array}\right]=\left[\begin{array}{l}
Z_{1, t-1} \\
Z_{2, t-1} \\
Z_{3, t-1}
\end{array}\right]+\left[\begin{array}{lll}
1 & 0 & 0 \\
0 & 1 & 0 \\
0 & 0 & 1
\end{array}\right]\left[\begin{array}{l}
a_{1, t} \\
a_{2, t} \\
a_{3, t}
\end{array}\right]-\left[\begin{array}{ccc}
0,958 & -0,431 & 0,179 \\
0,199 & 1,025 & -0,203 \\
0,345 & -0,134 & 0,705
\end{array}\right]\left[\begin{array}{l}
a_{1, t-1} \\
a_{2, t-1} \\
a_{3, t-1}
\end{array}\right]}
\end{aligned}
$$

Refer to equation (10), then VIMA(2,1) models for each agriculture sector are:

$$
\begin{aligned}
& Z_{1, t}=Z_{1, t-1}+a_{1, t}-0,958 a_{1, t-1}+0,431 a_{2, t-1}-0,179 a_{3, t-1} \\
& Z_{2, t}=Z_{2, t-1}+a_{2, t}-0,199 a_{1, t-1}-1,025 a_{2, t-1}+0,203 a_{3, t-1} \\
& Z_{3, t}=Z_{3, t-1}+a_{3, t}-0,345 a_{1, t-1}+0,134 a_{2, t-1}-0,705 a_{3, t-1}
\end{aligned}
$$

The result of the parameter significance test form VIMA $(2,1)$ presented in Table 6.

Table 6. Parameters significance test for $\operatorname{VIMA}(2,1)$

\begin{tabular}{cccc}
\hline Parameters & t-statistic & p-value & Conclusion \\
\hline$\theta_{1,1-1}$ & -3.6184 & 0.0050 & \\
$\theta_{1,1-1}$ & 4.3649 & 0.0001 & \\
$\theta_{1,1-1}$ & -3.9397 & 0.0008 & \\
$\theta_{1,1-1}$ & -4.7287 & 0.0001 & \\
$\theta_{1,1-1}$ & 4.9441 & 0.0001 & Parameters are \\
$\theta_{1,1-1}$ & -3.5969 & 0.0070 & singnificant \\
$\theta_{1,1-3}$ & 4.8134 & 0.0001 & \\
$\theta_{1,2-3}$ & -3.9846 & 0.0090 & \\
$\theta_{1,3-3}$ & -4.1227 & 0.0001 & \\
\hline
\end{tabular}

From Table 6 , at the significance level $\alpha=5 \%$, all of the parameters model for $\operatorname{VIMA}(2,1)$ were significance.

\subsection{Diagnostic Test and Model Evaluation}

The results of diagnostic tests which include residuals independence test and residuals normality test were presented in Table 7.

Table 7. Diagnostic Test for Residual of VIMA $(2,1)$

\begin{tabular}{cccccc}
\hline \multicolumn{2}{c}{ Jarque-Berra normality test } & \multicolumn{2}{c}{ Ljung-Box independence test } & \multirow{2}{*}{ AIC } \\
\cline { 1 - 4 } JB & p-value & Conclusion & p-value & Conclusion & \\
\cline { 1 - 4 } 24.513 & 0.0000 & $\begin{array}{c}\text { Residuals are } \\
\text { not normally } \\
\text { distributed }\end{array}$ & $\begin{array}{c}\text { For every } k \text {, the } \\
\text { value of } \rho_{k} \text { have } \\
\text { prob }>\alpha(0,05)\end{array}$ & $\begin{array}{c}\text { Residuals are } \\
\text { independent }\end{array}$ & -4.5720 \\
\hline
\end{tabular}

The AIC value for $\operatorname{VIMA}(2,1)$ was -4.5720 , it shows that the model suitable to forecast the FER value. Furthermore, from Ljung-Box test It is concluded that based on the Ljung-Box test the residuals are independent. However, based on Jarque-Berra test the residuals model 
are not satisfy normality assumptions. Although the residuals are not stationer, but it can be ignored.

\subsection{Forecast and Accuracy Measurement}

The results of FER forecast for the next 6 periods using the VIMA model $(2,1)$ are given in Table 8.

Table 8. Forecasts of FER Value for July 2017 to December 2017

\begin{tabular}{crrrrrr}
\hline \multirow{2}{*}{ Period } & \multicolumn{2}{c}{ Rice and Palawija } & \multicolumn{2}{c}{ Horticulture } & \multicolumn{2}{c}{ Fisheries } \\
\cline { 2 - 7 } & \multicolumn{1}{c}{ Actual } & \multicolumn{1}{c}{ Forecast } & Actual & Forecast & Actual & Forecast \\
\hline Jul-17 & 94.76 & 92.10 & 101.19 & 103.21 & 102.39 & 99.74 \\
Aug-17 & 96.75 & 95.32 & 101.78 & 104.01 & 102.78 & 100.19 \\
Sep-17 & 99.05 & 97.85 & 101.57 & 98.18 & 103.91 & 106.22 \\
Oct-17 & 101.20 & 103.74 & 99.82 & 97.41 & 103.06 & 98.87 \\
Nov-17 & 101.98 & 102.79 & 99.88 & 96.54 & 102.38 & 100.77 \\
Dec-17 & 103.14 & 105.84 & 99.54 & 100.91 & 102.77 & 102.89 \\
\hline
\end{tabular}

For measure the accuracy of forecasts, it is seen from MAPE value. The following table is MAPE value for each agricultural sector:

Table 9. MAPE value

\begin{tabular}{cccc}
\hline & Rice and Palawija & Horticulture & Fisheries \\
\hline MAPE & $1.91 \%$ & $2.44 \%$ & $2.18 \%$ \\
Forecasts Accuracy & Highly accurate & Highly accurate & Highly accurate \\
\hline
\end{tabular}

Based on MAPE value obtained from Table 9, the VIMA model $(2,1)$ was able to predict the FER value that closes to the actual value. It was because of the value of MAPE less than $10 \%$.

\section{CONCLUSION}

Based on the results and discussion, it is conclusive that the best model for modelling and forecast FER value of rice \& palawija, horticulture, and fisheries agriculture sectors in Central Java Province for the period of January 2011 to December 2017 is the VIMA $(2,1)$ model with:

$$
\begin{aligned}
& Z_{1, t}=Z_{1, t-1}+a_{1, t}-0,958 a_{1,-1}+0,431 a_{2,-1}-0,179 a_{3,-1} \\
& Z_{2, t}=Z_{2, t-1}+a_{2, t}-0,199 a_{1,-1}-1,025 a_{2,-1}+0,203 a_{3,-1} \\
& Z_{3, t}=Z_{3, t-1}+a_{3, t}-0,345 a_{1, t-1}+0,134 a_{2,-1}-0,705 a_{3,-1}
\end{aligned}
$$

$\mathrm{Z}_{1}$,: rice \& palawija, $\mathrm{Z}_{2}$ : horticulture, and $\mathrm{Z}_{3}$ : fisheries. By using MAPE, the results of forecast accuracy test were less than $10 \%$, this means that the $\operatorname{VIMA}(2,1)$ has high accuracy.

\section{ACKNOWLEDGEMENT}

I would like to thanks to Dr. Utriweni Mukhaiyar and Dr. Di Asih I Maruddani for all of her suggestion, comments, and support for this research. 


\section{REFERENCES}

Ayudhiah, M. P., Bahri, S., \& Fitriyani, N. (2020). Peramalan Indeks Harga Konsumen Kota Mataram Menggunakan Vector Autoregressive Integrated Moving Average. Eigen Mathematics Journal, 1(2), 1-8. https://doi.org/10.29303/emj.v1i2.61

BPS Provinsi Jawa Tengah. (2020). Jawa Tengah Province in Figure 2020. In BPS Jawa Tengah 2020. BPS Jawa Tengah. https://ngawikab.bps.go.id/publikasi.html

Charles, A., Darné, O., \& Tripier, F. (2015). Are Unit Root Tests Useful in the Debate over the (non) Stationarity of Hours Worked? Cambridge University Press (CUP), 19(1), 167-188.

Chen, B., Choi, J., \& Escanciano, J. C. (2017). Testing for Fundamental Vector Moving Average Representations. Quantitative Economics, 8(1), 149-180. https://doi.org/ 10.3982/qe393

Desvina, A. P., \& Meijer, O. I. (2018). Penerapan Model ARCH/GARCH untuk Peramalan Nilai Tukar Petani. Jurnal Sains Matematika Dan Statistika, 4(1), 43-54.

Dias, G. F., \& Kapetanios, G. (2014). Estimation and forecasting in vector autoregressive moving average models for rich datasets. Journal of Econometrics, 202(1), 75-91. https://doi.org/10.1016/j.jeconom.2017.06.022

Istiqomah, W., \& Darsyah, M. Y. (2018). Efektivitas Metode Arima Dan Exponential Smoothing Untuk Meramalkan Nilai Tukar Petani Di Jawa Tengah Effectiveness of the Arima Method and Exponential Smoothing to Predict Farmer Exchange Rates in Central Java. Prosiding Seminar Nasional Mahasiswa Unimus, 1(1), 343-350.

Keumala, C. M., \& Zainuddin, Z. (2018). Indikator Kesejahteraan Petani melalui Nilai Tukar Petani ( NTP ) dan Pembiayaan Syariah sebagai Solusi. Economica: Jurnal Ekonomi Islam, 9(1), 129-149.

Martina, \& Praza, R. (2018). Analisis Tingkat Kesejahteraan Petani Padi Sawah di Kabupaten Aceh Utara. Jurnal AGRIFO, 3(2), 27-34.

Maruddani, D. A. I., \& Trimono. (2018). Modeling Stock Prices in a Portfolio using Multidimensional Geometric Brownian Motion. Journal of Physics: Conference Series, 1025(1). https://doi.org/10.1088/1742-6596/1025/1/012122

Moreno, J. J. M., Pol, A. P., Abad, A. S., \& Blasco, B. C. (2013). El índice R-MAPE como medida resistente del ajuste en la previsiońn. Psicothema, 25(4), 500-506. https://doi.org/10.7334/psicothema2013.23

Nirmala, A., Hanani, N., \& Muhaimin, A. (2016). Analisis Faktor Faktor yang Mempengaruhi Nilai Tukar Petani Tanaman Pangan di Kabupaten Jombang. Habitat, 27(2), 66-71. https://doi.org/10.21776/ub.habitat.2016.027.2.8

Putri, C. K., \& Noor, T. I. (2018). Analisis Pendapatan dan Tingkat Kesejahteraan Rumah Tangga Petani Padi Sawah Berdasarkan Luas Lahan di Desa Sindangsari, Kecamatan Banjarsari, Kabupaten Ciamis, Provinsi Jawa Barat. Jurnal Ilmiah Mahasiswa Agroinfo Galuh, 4(3), 927-935.

R. Free Software Foundation's GNU General Public License. (2020).

Rachmat, M. (2013). Nilai Tukar Petani: Konsep, Pengukuran dan Relevansinya sebagai Indikator Kesejahteraan Petani. Forum Penelitian Agro Ekonomi, 31(2), 111. https://doi.org/10.21082/fae.v31n2.2013.111-122 
Setiawan, R. A. P., Noor, T. I., Sulistyowati, L., \& Setiawan, I. (2018). Analisis Tingkat Kesejahteraan Petani Kedelai dengan Menggunakan Pendekatan Nilai Tukar Petani (NTP) dan Nilai Tukar Pendapatan Rumah Tangga Petani (NTPRP). Jurnal Agribisnis Terpadu, 12(2), 178-189. https://jurnal.untirta.ac.id/index.php/jat/ article/download/6779/4702

Simionescu, M. (2013). The Use of VARMA Models in Forecasting Macroeconomic Indicators. Economics and Sociology, 6(2), 94-102. https://doi.org/10.14254/2071789X.2013/6-2/9

Wei, W. W. S. (2006). Tme Series Analysis, Univariate and Multivariate Methods. Addison Wesley Publishing Company. https://doi.org/10.2307/1269015

Zadrozny, P. A., \& Chen, B. (2019). Weighted-Covariance Factor Decomposition of Varma Models Applied to Forecasting Quarterly U.S. Real GDP at Monthly Intervals. Journal of Time Series Analysis, 40(6), 968-986. https://doi.org/10.1111/jtsa.12506

Zhao, X., \& Qian, G. (2014). On Multivariate Time Series Model Selection Involving Many Candidate VAR Models. European Journal of Pure and Applied Mathematics, 7(1), $1-21$. 